\title{
Effects of pollen, sugars and honeydew on lifespan and nutrient levels of Episyrphus balteatus
}

\author{
Lara A. Pinheiro • Laura M. Torres • \\ João Raimundo $\cdot$ Sónia A. P. Santos
}

Received: 30 April 2014/Accepted: 15 September 2014/Published online: 21 September 2014

(C) International Organization for Biological Control (IOBC) 2014

\begin{abstract}
Hoverflies require pollen, nectar and honeydew during their adult stage, but little is known about the suitability and nutrient provision of each of those resources. Thus, in this study we assessed the effect of different types of food, such as carbohydrates (glucose, fructose, sucrose and honey), pollen, a mixture of honey and pollen, and honeydew on longevity and nutrient levels of Episyrphus balteatus (De Geer) (Diptera: Syrphidae). Glucose and the mixture of pollen and honey were the food sources that gave the highest longevities. Considering nutrient levels in the body of hoverflies, sucrose generated high levels of fructose, total sugars and glycogen while glucose generated high levels of lipids. This suggests
\end{abstract}

Handling Editor: Patrick De Clercq.

L. A. Pinheiro · J. Raimundo - S. A. P. Santos $(\square)$ Mountain Research Center, CIMO, School of Agriculture, Polytechnic Institute of Bragança, IPB, Campus Sta Apolónia, Apt. 1171, 5301-855 Bragança, Portugal e-mail: saps@ipb.pt

L. M. Torres

Centre for the Research and Technology of AgroEnvironmental and Biological Sciences, CITAB, University of Trás-os-Montes and Alto Douro, UTAD, Quinta de Prados, 5000-801 Vila Real, Portugal

Present Address:

J. Raimundo

IMAR-CMA, Department of Life Sciences, University of Coimbra, 3004-517 Coimbra, Portugal that carbohydrates are important food components for the survival and energy supply of hoverflies, with glucose being the most effective. Honeydew can also be used by hoverflies, representing a significant sugar source that may replace nectar when suitable flowers are scarce in agroecosystems.

Keywords Syrphidae $\cdot$ Survival $\cdot$ Glucose $\cdot$ Honeydew · Nutrient levels

\section{Introduction}

Hoverflies (Diptera: Syrphidae) are important insects in agroecosystems, providing essential services to the farmers such as biological control and pollination (Gilbert 1981). The larvae of predaceous hoverflies are potential biological control agents of a range of Sternorrhyncha pests, mainly aphids and psyllids (Bugg et al. 2008; Ksantini 2003; Rojo et al. 2003). On the other hand, adult hoverflies are highly dependent on nectar and honeydew, basically sources of carbohydrates for energy, to sustain flight and metabolism, and pollen, basically proteins, for sexual maturation (Gilbert 1981; Haslett 1989a; Laubertie et al. 2012). Thus, the availability of plant resources in agricultural fields has been considered as an essential requirement for enhancing survival and reproduction of hoverflies (Langoya and van Rijn 2008; Laubertie et al. 2012; Pinheiro et al. 2013a, 2013b; van Rijn et al. 2013). However, agricultural intensification resulted 
in the simplification of the landscape and a consequent scarcity of flowering plants that sustain these beneficial insects (Bianchi et al. 2006). Promoting the implementation of floral resources in agroecosystems may be a sustainable way to improve the abundance of hoverflies for a more effective biological control of pests (Haenke et al. 2009; Ricarte et al. 2011).

Plant species such as sweet alyssum (Lobularia maritima L. Desv.), coriander (Coriandrum sativum L.), phacelia (Phacelia tanacetifolia Benth.), fennel (Foeniculum vulgare Mill.), buckwheat (Fagopyrum esculentum Moench) and common mallow (Malva sylvestris L.) have been referred to as useful non-crop plants that enhance longevity and fecundity of adult hoverflies (Ambrosino et al. 2006; Colley and Luna 2000; Laubertie et al. 2012; Nicholls et al. 2001; Pineda and Marcos-García 2008; Pinheiro et al. 2013b; White et al. 1995), mainly gravid females (Irvin et al. 1999). The amount and accessibility of pollen and nectar produced by these plants can have a significant effect on the performance of hoverflies. Pollen is the main source of amino acids and according to Haslett (1989b), hoverflies can take nutrients from pollen even if they cannot digest the exine. Nectar is a source of energy mainly composed of sucrose, glucose and fructose as well as of other sugars and several amino acids represented in low concentrations (Nicolson and Thornburg 2007; Petanidou et al. 2006).

At sufficient Sternorrhyncha densities, either on infested crop or non-crop plants, the honeydew produced by these sap-sucking insects may even be used by hoverflies as a supplementary source of sugars (van Rijn et al. 2013). Although the composition of the honeydew depends on the insect and host plant interaction, sucrose, fructose and glucose are among the most abundant sugars commonly found in honeydew. Besides, honeydew also contains other oligosaccharides which are less common or inexistent in floral nectar (Wäckers 2001). Previous studies showed that survival and oviposition rate were favoured in Episyrphus balteatus (De Geer) in the presence of aphid honeydew (Scholz and Poehling 2000; van Rijn et al. 2013).

Despite the relative contribution of each naturally occurring food source (pollen, nectar and honeydew) to adult lifespan, little is known about the suitability of each of these foods and individual carbohydrates for hoverflies. It is expected that each food source influences longevity and also nutrient levels (sugars, glycogen and lipids) of hoverflies in different ways. Accordingly, the objective of this study was to obtain an overview of the nutrient utilization by E. balteatus of pollen, honeydew and different carbohydrates and compare their effects on longevity. The honeydew tested was obtained from the black scale, Saissetia oleae (Olivier) (Hemiptera: Coccidae), and was chosen because (i) scale honeydew was never tested on $E$. balteatus, (ii) the black-scale is a cosmopolitan pest hosted by several plant species including citrus, olives as well as ornamental trees and shrubs (e.g. Nerium oleander L.) (Noguera et al. 2003; Panis 1977; Santos et al. 2010) and (iii) throughout the year, the black scale honeydew can be the main resource in intensive crops in the Mediterranean region, helping to maintain hoverflies in agroecosystems or even supporting their migratory flights when searching for oviposition sites.

\section{Materials and methods}

\section{Hoverflies}

Episyrphus balteatus were purchased from Koppert Biological Systems (Berkel en Rodenrijs, The Netherlands) and were supplied in the pupal stage. In the laboratory, E. balteatus pupae were held in plastic cages $(4.5 \times 7.5 \mathrm{~cm})$ with a moistened filter paper and a perforated lid. Plastic cages were placed in a climate chamber at $21 \pm 1{ }^{\circ} \mathrm{C}, 70 \pm 5 \%$ relative humidity (RH), and a photoperiod of 16:8 (L:D) h till emergence of adults. Newly emerged hoverflies were paired and 50 individuals of E. balteatus (25 males and 25 females) were used for each diet. In addition and as a reference of initial nutrient levels before feeding, a second group of 50 unfed newly emerged $(<24 \mathrm{~h})$ individuals of E. balteatus ( 25 males and 25 females) was immediately frozen and stored at $-20{ }^{\circ} \mathrm{C}$ for further assays.

\section{Food sources}

The food sources tested were: bee-collected pollen obtained from an organic beekeeper, commercial organic honey (as mimic for nectar), two monosaccharides (D-(-)-fructose $\geq 99 \%$ and $\mathrm{D}$ - $(+)$-glucose $\geq 99 \%$, purchased from Acros Organics, Geel, Belgium), a disaccharide (D-(+)-sucrose $\geq 99 \%$, purchased from Fisher Scientific, Leicestershire, UK 
and S. oleae honeydew. Saissetia oleae (not a prey item for hoverflies) was reared on small olive trees in a climate chamber at $24 \pm 1{ }^{\circ} \mathrm{C}, 70 \pm 5 \% \mathrm{RH}$ and a photoperiod of 16:8 h(L:D).

\section{Longevity}

For the longevity experiment, cylindrical cages of $21 \mathrm{~cm}$ height and $9 \mathrm{~cm}$ in diameter were used. The wall was made from a colourless acetate sheet, a plastic Petri dish formed the top and another plastic cup formed the basis of the cage. The ventilation inside the cage was assured by multiple perforations in the acetate sheet. Female and male E. balteatus were kept with one of the following diets: (1) water only (starved - negative control), (2) honey at a solution of $10 \%(\mathrm{v} / \mathrm{v}),(3)$ fructose, (4) glucose and (5) sucrose at solutions of $1 \mathrm{M}$, (6) moist powdered pollen $(0.5 \mathrm{~g})$, (7) honey at a solution of $10 \%$ and moist powdered pollen ( $0.5 \mathrm{~g})$, and (8) S. oleae honeydew. Water was also provided in all diet treatments.

Pairs of newly emerged individuals were placed in each cylindrical plastic cage and presented with one of the diets mentioned above. Fifty individuals of $E$. balteatus (25 males and 25 females) were used for each treatment. Water and the solutions of honey, fructose, glucose and sucrose were provided by filling a $3 \mathrm{ml}$ glass vial fitted with a strip of an absorbent cloth through a hole in the cap of the vial. Moist powdered pollen was placed on a strip of cloth. Each diet was changed every two days. Saissetia oleae honeydew was collected by placing overnight a Parafilm $(\subset$ strip under infested leaves and this diet was changed every day. Cages were kept in a climate chamber at $21 \pm 1{ }^{\circ} \mathrm{C}, 70 \pm 5 \% \mathrm{RH}$, and a photoperiod of 16:8 (L:D) $\mathrm{h}$ and checked for insect survival on a daily basis. Dead hoverflies were promptly removed, labeled and stored at $-20{ }^{\circ} \mathrm{C}$ for further analyses.

\section{Nutrient levels analysis}

Nutrient levels (fructose, total sugars, lipids and glycogen) in hoverflies were quantified in adult females and males of E. balteatus derived from the longevity experiments and in newly emerged specimens. Levels of fructose, total sugars, lipids and glycogen were quantified in individual hoverflies using a series of biochemical tests adapted from van
Handel (1985a, b) and Fadamiro et al. (2005). Fructose levels were quantified in order to assess the amount of this monosaccharide in the gut, while total sugars, glycogen and lipids were quantified to assess energy reserves. Each hoverfly was crushed with a plastic pestle in a $1.5 \mathrm{ml}$ microcentrifuge tube containing $100 \mu \mathrm{l}$ of $2 \%$ sodium sulphate solution and $900 \mu \mathrm{l}$ of chloroform-methanol $(1: 1)$, after which the tube was vortexed and placed on ice. The mixture was centrifuged at 13,200 rpm for 4 min at $4{ }^{\circ} \mathrm{C}$ and $50 \mu \mathrm{l}$ of the resulting supernatant was transferred to a $1.5 \mathrm{ml}$ microcentrifuge tube for further analyses of fructose and total sugars and $50 \mu \mathrm{l}$ from the lower layers of the mixture were transferred to another $1.5 \mathrm{ml}$ microcentrifuge tube for lipid analysis. The remaining supernatant was discarded and the precipitate was kept in the $1.5 \mathrm{ml}$ microcentrifuge tube for glycogen analysis. For each of the nutrients described below, a blank tube was run alongside, following the same procedure of the samples.

\section{Fructose analysis}

$950 \mu \mathrm{l}$ of anthrone reagent was added to the $50 \mu \mathrm{l}$ solution in the $1.5 \mathrm{ml}$ microcentrifuge tube, vortexed and left to react at room temperature for $1 \mathrm{~h} 30 \mathrm{~min}$ (cold anthrone test). After the reaction time had elapsed, the solution was poured into a $1.5 \mathrm{ml}$ methacrylate cuvette and the absorbance measured at $625 \mathrm{~nm}$ using a spectrophotometer. Absorbance readings were converted to absolute fructose amounts $(\mu \mathrm{g})$, using fructose standard curves generated by determining the cold anthrone absorbance (at $625 \mathrm{~nm}$ ) of different amounts of fructose ranging from 0 to $50 \mu \mathrm{g}$, in triplicate per dose. This amount was then multiplied by a factor of 20 because only $50 \mu$ of the original $1 \mathrm{ml}$ was used for the fructose assay.

\section{Total sugars analysis}

The same solution used for the cold anthrone test was poured back into the previous $1.5 \mathrm{ml}$ microcentrifuge tube, heated at $90{ }^{\circ} \mathrm{C}$ for $10 \mathrm{~min}$ and cooled on ice. The absorbance was read at $625 \mathrm{~nm}$ to give an estimate of total sugars (hot anthrone test). Absorbance readings were converted to absolute amounts $(\mu \mathrm{g})$, using sucrose standard curves generated by determining the hot anthrone absorbance (at $625 \mathrm{~nm}$ ) of different amounts of sucrose ranging from 0 to 
$50 \mu \mathrm{g}$, in triplicate. The absolute amount of total sugars present in each hoverfly was estimated by multiplying the amount of sugars from the hot anthrone test by 20 because only $50 \mu \mathrm{l}$ of the original $1 \mathrm{ml}$ was used.

\section{Glycogen analysis}

The amount of glycogen was estimated by adding $1 \mathrm{ml}$ of anthrone reagent to the $1.5 \mathrm{ml}$ microcentrifuge tube containing the precipitate. After vortexing, tubes were heated at $90{ }^{\circ} \mathrm{C}$ for $10 \mathrm{~min}$ and then cooled on ice and the absorbance read at $625 \mathrm{~nm}$. Absorbance readings were converted to absolute glycogen amounts $(\mu \mathrm{g})$ using glycogen standard curves generated by determining the absorbance (at $625 \mathrm{~nm}$ ) of different amounts of glycogen from oyster (Sigma-Aldrich, Steinheim, Germany), ranging from 0 to $125 \mathrm{ml}$, in triplicate. The amount of glycogen estimated above was considered to be representative of the whole hoverfly because all glycogen in the sample is presumed to precipitate to the bottom of the tube.

\section{Lipid analysis}

The different batches of $1.5 \mathrm{ml}$ microcentrifuge tubes with $50 \mu \mathrm{l}$ of solution for the lipid analysis were heated at $90{ }^{\circ} \mathrm{C}$ for complete evaporation of the solution. $40 \mu \mathrm{l}$ of sulfuric acid was added and heated at $90{ }^{\circ} \mathrm{C}$ for $2 \mathrm{~min}$ followed by ice cooling of the samples. $960 \mu \mathrm{l}$ of vanillin phosphoric acid was added to the new solution, vortexed and left to react at room temperature for $30 \mathrm{~min}$. After the reaction time had elapsed, the solution was poured into a $1.5 \mathrm{ml}$ methacrylate cuvette and the absorbance was measured at $525 \mathrm{~nm}$ using a spectrophotometer. Absorbance readings were converted to absolute lipid amounts $(\mu \mathrm{g})$, using lipid standard curves generated by determining the vanillin absorbance (at $525 \mathrm{~nm}$ ) of different amounts of soybean oil (Sigma-Aldrich, Steinheim, Germany) ranging from 0 to $200 \mu \mathrm{l}$, in triplicate. This amount was then multiplied by a factor of 20 because only $50 \mu \mathrm{l}$ of the original $1 \mathrm{ml}$ was used for the lipid assay.

When the nutrient levels measures in E. balteatus were very high it was necessary to dilute the initial $50 \mu \mathrm{l}$ of the original $1 \mathrm{ml}$ in $5-9 \mathrm{ml}$ of each solution for fructose, total sugars, glycogen and lipid analyses in order to enable reading of absorbance.
Data analysis

Statistical analyses were performed with IBM-SPSS statistics, version 19.0.0 (SPSS Inc. IBM Company 2010). The normal distribution of the residuals and the homogeneity of variances were evaluated by means of the Kolmogorov-Smirnov and Levene's tests, respectively. Longevity and nutrient analyses were conducted for comparison among treatments and sex by using general linear models to test the effects of treatment, sex and treatment $\times$ sex, followed by the Tukey-Kramer HSD test.

Survival curves were generated and compared using Kaplan-Meier estimates of the function "Survdiff" from the "survival" package in R (R Core Team 2014). A log-rank or Mantel-Haenszel test was used to account for each of the pair-wise comparisons. In this case, the Bonferroni correction was applied in order to avoid false significant effects by random chance.

All statistical tests were performed at $5 \%$ significance level. Data are presented as mean values \pm 1 standard error (SE).

\section{Results}

\section{Longevity}

The different treatments had a significant effect on the longevity of E. balteatus but neither the sex nor the treatment $\times$ sex interaction were significant (Table 1 ). There was a highly significant effect of the different food sources on longevity, compared to the water only treatment (Table 2). The food sources that gave higher values of female longevity were glucose $(1 \mathrm{M})$ with 14.08 days, honey $10 \%+$ pollen with 13.60 days, honey $(10 \%)$ and pollen, both with 11.96 days. Different results were obtained for male hoverflies that showed higher longevities when fed on honey $(10 \%)$ with 13.96 days, glucose $(1 \mathrm{M})$ with 13.76 days, honey $10 \%+$ pollen with 12.08 days and sucrose $(1 \mathrm{M})$ with 11.00 days (Table 2). The mean longevity of E. balteatus fed on glucose was 7.64 times greater in males and 7.65 times in females than the mean longevity of individuals fed on water only (Table 2). E. balteatus fed on black scale honeydew and fructose had significantly lower longevities (4.32 and 7.42 days, respectively) when compared with the other food sources. However, these 
Table 1 Results of ANOVA for longevity, and levels of fructose, other sugars, glycogen and lipids in Episyrphus balteatus, $\mathrm{n}=50$

\begin{tabular}{|c|c|c|c|}
\hline & df & $\mathrm{F}$ & $\mathrm{P}$ \\
\hline \multicolumn{4}{|l|}{ Longevity } \\
\hline Treatment & 7,384 & 123.758 & $<0.001$ \\
\hline Sex & 1,384 & 0.132 & 0.716 \\
\hline Treatment $\times$ Sex & 7,384 & 1.863 & 0.074 \\
\hline \multicolumn{4}{|l|}{ Fructose } \\
\hline Treatment & 4,240 & 19.990 & $<0.001$ \\
\hline Sex & 1,240 & 0.823 & 0.365 \\
\hline Treatment $\times$ Sex & 4,240 & 0.127 & 0.972 \\
\hline \multicolumn{4}{|l|}{ Other Sugars } \\
\hline Treatment & 7,384 & 85.321 & $<0.001$ \\
\hline Sex & 1,384 & 1.017 & 0.314 \\
\hline Treatment $\times$ Sex & 7,384 & 1.177 & 0.315 \\
\hline \multicolumn{4}{|l|}{ Glycogen } \\
\hline Treatment & 8,432 & 58.219 & $<0.001$ \\
\hline Sex & 1,432 & 0.874 & 0.350 \\
\hline Treatment $\times$ Sex & 8,432 & 0.856 & 0.554 \\
\hline \multicolumn{4}{|l|}{ Lipids } \\
\hline Treatment & 8,432 & 51.604 & $<0.001$ \\
\hline Sex & 1,432 & 2.015 & 0.156 \\
\hline Treatment $\times$ Sex & 8,432 & 0.501 & 0.855 \\
\hline
\end{tabular}

two treatments yielded significant differences when compared with individuals fed on water only (Table 2). Sucrose was the only treatment with significant differences between sexes in terms of longevity, resulting in significantly higher longevities for males than for females.
Females

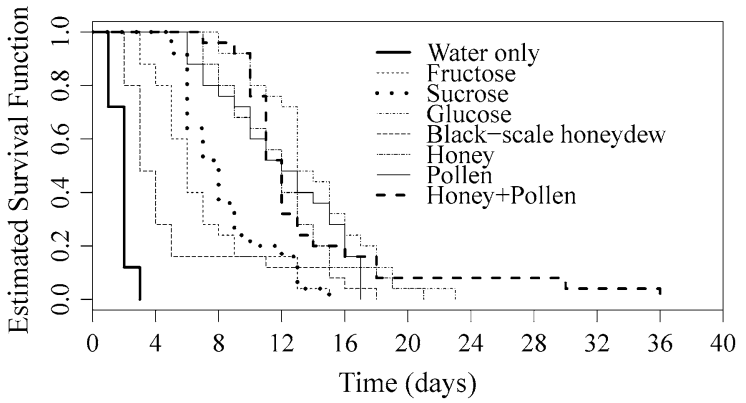

Males

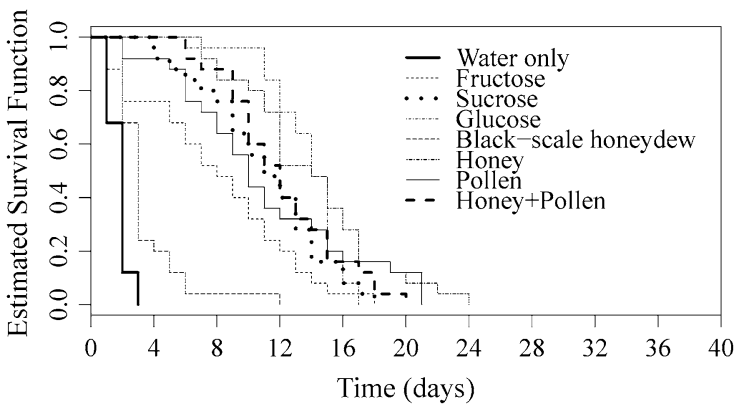

Fig. 1 Kaplan-Meier estimates of the survival functions of females and males of Episyrphus balteatus provided with water only, fructose, glucose, sucrose, black-scale honeydew, honey, pollen or honey + pollen

Survival curves for both sexes differed significantly among treatments (females: $\chi^{2}=254$; d.f. $=7$, $P<0.001$; males: $\chi^{2}=186$, d.f. $=7, P<0.001$; Fig. 1). Females survived significantly longer when fed on honey + pollen, glucose, honey and pollen when compared with the other four treatments and no

Table 2 Longevity (mean \pm SE) of Episyrphus balteatus adults on each food source tested and water only, $\mathrm{n}=25$ for females and males, $\mathrm{n}=50$ for total

\begin{tabular}{lrrr}
\hline Treatments & \multicolumn{2}{c}{ Longevity (days) } & \\
\cline { 2 - 4 } & \multicolumn{1}{l}{ Male } & \multicolumn{1}{c}{ Female } & Total \\
\hline Water only & $1.80 \pm 0.13^{\mathrm{d}}$ & $1.84 \pm 0.12^{\mathrm{d}}$ & $1.82 \pm 0.09^{\mathrm{f}}$ \\
Fructose & $7.92 \pm 0.97^{\mathrm{b}}$ & $6.92 \pm 0.67^{\mathrm{b}}$ & $7.42 \pm 0.59^{\mathrm{d}}$ \\
Glucose & $13.76 \pm 0.48^{\mathrm{a}}$ & $14.08 \pm 0.73^{\mathrm{a}}$ & $13.92 \pm 0.44^{\mathrm{a}}$ \\
Sucrose & $11.00 \pm 0.79^{\mathrm{a}}$ & $8.32 \pm 0.57^{\mathrm{b}}$ & $9.66 \pm 0.52^{\mathrm{c} *}$ \\
Black-scale honeydew & $3.48 \pm 0.43^{\mathrm{c}}$ & $5.16 \pm 0.92^{\mathrm{c}}$ & $4.32 \pm 0.52^{\mathrm{e}}$ \\
Honey $10 \%$ & $13.96 \pm 0.90^{\mathrm{a}}$ & $11.96 \pm 0.75^{\mathrm{a}}$ & $12.96 \pm 0.60^{\mathrm{ab}}$ \\
Pollen & $10.96 \pm 1.12^{\mathrm{a}}$ & $11.96 \pm 0.78^{\mathrm{a}}$ & $11.46 \pm 0.68^{\mathrm{cb}}$ \\
Honey $10 \%+$ Pollen & $12.08 \pm 0.75^{\mathrm{a}}$ & $13.60 \pm 1.28^{\mathrm{a}}$ & $12.84 \pm 0.74^{\mathrm{ab}}$ \\
\hline
\end{tabular}

Means within a column with the same letter are not significantly different at $p<0.05$

The asterisk indicates that females and males had significantly different longevities for the same food source at $p<0.05$ 
Table 3 Fructose contents (mean $\pm \mathrm{SE}$ ) in Episyrphus balteatus for adults fed on each food source tested, water only and for newly emerged individuals; $\mathrm{n}=25$ per treatment for females and males, $\mathrm{n}=50$ per treatment for total

Means within a column followed by the same letter are not significantly different at $p<0.05$

\begin{tabular}{llll}
\hline Treatments & \multicolumn{2}{l}{ Fructose $\left(\mu \mathrm{g} \mathrm{ml}^{-1}\right)$} & \\
\cline { 2 - 4 } & Male & Female & Total \\
\hline Newly emerged & 0 & 0 & 0 \\
Water only & 0 & 0 & 0 \\
Fructose & $307.29 \pm 62.01^{\mathrm{a}}$ & $493.61 \pm 100.53^{\mathrm{a}}$ & $400.45 \pm 59.95^{\mathrm{a}}$ \\
Glucose & 0 & 0 & 0 \\
Sucrose & $695.00 \pm 152.95^{\mathrm{a}}$ & $698.25 \pm 116.94^{\mathrm{a}}$ & $696.62 \pm 95.28^{\mathrm{a}}$ \\
Honeydew & 0 & 0 & 0 \\
$\quad$ black scale & $99.65 \pm 39.34^{\mathrm{b}}$ & $96.53 \pm 29.29^{\mathrm{b}}$ & $98.09 \pm 24.28^{\mathrm{b}}$ \\
Honey 10 \% & $65.04 \pm 18.03^{\mathrm{b}}$ & $60.31 \pm 17.91^{\mathrm{b}}$ & $62.68 \pm 12.58^{\mathrm{b}}$ \\
Pollen & $68.91 \pm 29.05^{\mathrm{b}}$ & $89.75 \pm 24.84^{\mathrm{b}}$ & $79.33 \pm 19.97^{\mathrm{b}}$ \\
Honey $10 \%+$ Pollen & & & \\
\hline
\end{tabular}

significant differences were found among those treatments. Males survived longer when fed on honey, but no significant differences were found between that treatment and pollen or honey + pollen. When offered black scale honeydew, some individual hoverflies survived up to 18 days (for females) and 12 days (for males). Survival was significantly higher than that recorded in the water only treatment (females: $\chi^{2}=28$, d.f. $=1, P<0.001$; males: $\chi^{2}=$ 20.5 , d.f. $=1, P<0.001$ ) (Fig. 1) and no significant differences were found, for females, between black scale honeydew and fructose treatments $\left(\chi^{2}=2.6\right.$, d.f. $=1, P=0.106)$.

\section{Body nutrient analysis}

Episyrphus balteatus showed a variable distribution of nutrient levels resulting from the different treatments. Fructose was detected only in individuals fed on fructose, sucrose, honey, pollen and honey + pollen (Table 3). The highest levels of fructose were detected in females and males fed on sucrose followed by fructose (696.62 and $400.45 \mu \mathrm{g} \mathrm{ml}^{-1}$, respectively), although no statistically significant differences were found between these two treatments (Table 3).

In relation to the levels of other sugars in the body of hoverflies, only individuals fed on pollen and black scale honeydew presented statistically significant lower values than the newly emerged ones (Table 4). In the case of the water only treatment, the levels of other sugars were detected only in three individuals out of 50 analyzed (two females with 14.80 and $56.28 \mu \mathrm{g} \mathrm{ml}^{-1}$ and one male with $155.84 \mu \mathrm{g} \mathrm{ml}^{-1}$ ). The highest levels were obtained in males and females fed on sucrose, fructose and glucose (Table 4). Females fed on fructose contained significantly higher levels of other sugars than males (Table 4). The levels of fructose and other sugars were not significantly influenced by sex and treatment $\times$ sex interaction (Table 1).

Glycogen levels were higher in individuals fed on sucrose and fructose $\left(700.76,503.80 \mu \mathrm{g} \mathrm{ml}^{-1}\right.$, respectively) and the differences between sexes were not statistically significant (Table 5). On the other hand, the lowest levels of glycogen were registered in individuals fed on pollen, black scale honeydew, water only and honey + pollen. Glycogen levels were influenced by treatment but not by sex and treatment $\times$ sex interaction (Table 1 ).

The highest lipid levels were measured in individuals fed on glucose $\left(703.44 \mu \mathrm{g} \mathrm{ml}^{-1}\right.$ for males and $636.21 \mu \mathrm{g} \mathrm{ml}^{-1}$ for females), although no statistically significant differences were found between adults offered this food source and the newly emerged individuals. The lipid levels were significantly higher in males than in females fed on sucrose (Table 6).

\section{Discussion}

The results show that female and male E. balteatus are able to feed on all the food sources provided in this study, since their lifespan significantly increased when compared with individuals fed on water only. At the nutritional level, hoverflies emerged with high capital reserves (nutrients that are acquired during the larval stage and used during the adult stage) of sugars, lipids and glycogen. However, after two or three days 
Table 4 Total sugar contents (mean $\pm \mathrm{SE}$ ) in Episyrphus balteatus for adults fed on each food source tested, water only and for newly emerged individuals; $\mathrm{n}=25$ per treatment for females and males, $\mathrm{n}=50$ per treatment for total

\begin{tabular}{llll}
\hline Treatments & Other sugars $\left(\mu \mathrm{g} \mathrm{ml}^{-1}\right)$ & & Total \\
\cline { 2 - 4 } & Male & Female & $242.30 \pm 39.16^{\mathrm{b}}$ \\
\hline Newly emerged & $206.90 \pm 37.62^{\mathrm{d}}$ & $277.71 \pm 68.86^{\mathrm{c}}$ & - \\
Water only & - & - & $764.40 \pm 72.69^{\mathrm{a}^{*}}$ \\
Fructose & $573.86 \pm 80.98^{\mathrm{abc}}$ & $954.95 \pm 109.51^{\mathrm{ab}}$ & $723.20 \pm 60.36^{\mathrm{a}}$ \\
Glucose & $740.12 \pm 82.92^{\mathrm{ab}}$ & $706.28 \pm 89.31^{\mathrm{ab}}$ & $1,522.98 \pm 189.74^{\mathrm{a}}$ \\
Sucrose & $1,573.60 \pm 330.30^{\mathrm{a}}$ & $1,472.37 \pm 194.13^{\mathrm{a}}$ & $20.15 \pm 5.71^{\mathrm{d}}$ \\
Honeydew black scale & $27.27 \pm 9.69^{\mathrm{e}}$ & $13.04 \pm 5.92^{\mathrm{d}}$ & $279.92 \pm 37.63^{\mathrm{b}}$ \\
Honey 10 \% & $244.33 \pm 42.47^{\mathrm{cd}}$ & $315.52 \pm 62.22^{\mathrm{c}}$ & $77.52 \pm 15.88^{\mathrm{c}}$ \\
Pollen & $85.30 \pm 20.93^{\mathrm{e}}$ & $69.73 \pm 24.22^{\mathrm{d}}$ & $319.00 \pm 40.14^{\mathrm{b}}$ \\
Honey 10 $\%+$ Pollen & $261.83 \pm 36.76^{\mathrm{bcd}}$ & $376.16 \pm 70.39^{\mathrm{bc}}$ & \\
\hline
\end{tabular}

Means within a column followed by the same letter are not significantly different at $p<0.05$

The asterisk indicates that nutrient levels in females and males were significantly different for the same food source at $p<0.05$

Table 5 Glycogen contents (mean $\pm \mathrm{SE}$ ) in Episyrphus balteatus for adults fed on each food source tested, water only and for newly emerged individuals; $n=25$ per treatment for females and males, $\mathrm{n}=50$ per treatment for total

Means within a column followed by the same letter are not significantly different at $p<0.05$

\begin{tabular}{lccc}
\hline Treatments & \multicolumn{3}{l}{ Glycogen $\left(\mu \mathrm{g} \mathrm{ml}^{-1}\right)$} \\
\cline { 2 - 4 } & Male & Female & Total \\
\hline Newly emerged & $55.21 \pm 4.64^{\mathrm{bc}}$ & $54.21 \pm 3.93^{\mathrm{cd}}$ & $54.71 \pm 3.01^{\mathrm{cd}}$ \\
Water only & $28.54 \pm 5.48^{\mathrm{d}}$ & $26.37 \pm 4.74^{\mathrm{e}}$ & $27.45 \pm 3.59^{\mathrm{e}}$ \\
Fructose & $464.71 \pm 86.49^{\mathrm{ab}}$ & $542.88 \pm 90.70^{\mathrm{b}}$ & $503.80 \pm 62.27^{\mathrm{ab}}$ \\
Glucose & $278.24 \pm 31.17^{\mathrm{a}}$ & $265.52 \pm 33.58^{\mathrm{b}}$ & $271.88 \pm 22.69^{\mathrm{b}}$ \\
Sucrose & $625.30 \pm 115.09^{\mathrm{a}}$ & $776.21 \pm 94.47^{\mathrm{a}}$ & $700.76 \pm 74.47^{\mathrm{a}}$ \\
Honeydew & $28.46 \pm 1.02^{\mathrm{cd}}$ & $26.99 \pm 1.85^{\mathrm{de}}$ & $27.71 \pm 1.05^{\mathrm{de}}$ \\
$\quad$ black scale & $137.12 \pm 21.28^{\mathrm{b}}$ & $126.92 \pm 21.11^{\mathrm{c}}$ & $132.02 \pm 14.85^{\mathrm{c}}$ \\
Honey 10\% & $24.77 \pm 2.55^{\mathrm{c}}$ & $29.41 \pm 5.10^{\mathrm{de}}$ & $27.09 \pm 2.84^{\mathrm{e}}$ \\
Pollen & $33.27 \pm 2.30^{\mathrm{d}}$ & $32.32 \pm 3.20^{\mathrm{de}}$ & $27.25 \pm 2.06^{\mathrm{e}}$ \\
Honey $10 \%+$ Pollen & & &
\end{tabular}

feeding on only water, capital reserves (especially sugars) declined significantly. On the other hand, hoverflies mainly benefited from the ingestion of glucose, fructose and sucrose for which sugar and glycogen levels exceeded those measured in the newly emerged and water only fed individuals. This suggests that an ad libitum provision of $1 \mathrm{M}$ solutions of those carbohydrates resulted in high levels of food consumption and energy conversion. Nevertheless, glucose and sucrose (9-14 days) promoted longer lifespans than fructose (7-8 days). As Wäckers (1999) pointed out, the suitability of a sugar as food source is determined at the sensory level (it must be detectable by receptor cells and elicit a gustatory response) and at the physiological level (digestion and energy convertibility). Thus, a natural enemy will feed on a sugar source if it is able to perceive the different molecules. As found by Wacht et al. (2000), the receptor cells of the hoverfly Eristalis tenax (L.) (Diptera: Syrphidae) responded most strongly to sucrose and glucose, while fructose was less detectable by the fly. This probably suggests that, in our study, fructose was less consumed by E. balteatus than glucose and sucrose. This idea is supported by the levels of fructose measured in the gut of individuals fed on sucrose (a glucose-fructose disaccharide), which reached about twofold the levels of fructose measured in individuals fed on fructose (Table 3).

Sucrose, glucose and fructose are the dominant sugars in nectars (Petanidou et al. 1996) and are also found in honeydew (Davidson et al. 1994) and pollen (Stanley and Linskins 1974). Considering sugar 
Table 6 Lipid contents (mean \pm SE) in Episyrphus balteatus for adults fed on each food source tested, water only and for newly emerged individuals; $\mathrm{n}=25$ per treatment for females and males, $\mathrm{n}=50$ per treatment for total

\begin{tabular}{lrrr}
\hline Treatments & \multicolumn{2}{c}{ Lipids $\left(\mu \mathrm{g} \mathrm{ml}^{-1}\right)$} & \\
\cline { 2 - 4 } & \multicolumn{1}{l}{ Male } & \multicolumn{1}{c}{ Female } & Total \\
\hline Newly emerged & $517.63 \pm 45.88^{\mathrm{a}}$ & $465.65 \pm 41.05^{\mathrm{ab}}$ & $491.64 \pm 30.69^{\mathrm{a}}$ \\
Water only & $117.27 \pm 61.55^{\mathrm{c}}$ & $84.74 \pm 30.57^{\mathrm{hf}}$ & $101.01 \pm 34.09^{\mathrm{ce}}$ \\
Fructose & $184.10 \pm 30.76^{\mathrm{b}}$ & $151.28 \pm 28.69^{\mathrm{ef}}$ & $167.69 \pm 20.95^{\mathrm{be}}$ \\
Glucose & $703.44 \pm 48.60^{\mathrm{a}}$ & $636.21 \pm 51.59^{\mathrm{a}}$ & $669.82 \pm 35.40^{\mathrm{a}}$ \\
Sucrose & $635.84 \pm 62.75^{\mathrm{a}}$ & $348.16 \pm 43.40^{\mathrm{abc}}$ & $492.00 \pm 42.99^{\mathrm{a}}$ \\
Honeydew black scale & $63.79 \pm 5.62^{\mathrm{c}}$ & $142.73 \pm 55.12^{\mathrm{cef}}$ & $103.26 \pm 27.99^{\mathrm{c}}$ \\
Honey 10\% & $64.56 \pm 33.83^{\mathrm{c}}$ & $35.39 \pm 19.13^{\mathrm{h}}$ & $49.97 \pm 19.34^{\mathrm{e}}$ \\
Pollen & $198.15 \pm 28.45^{\mathrm{b}}$ & $227.18 \pm 49.25^{\mathrm{de}}$ & $212.66 \pm 28.22^{\mathrm{b}}$ \\
Honey $10 \%+$ Pollen & $102.86 \pm 23.00^{\mathrm{c}}$ & $260.19 \pm 172.47^{\mathrm{bd}}$ & $181.53 \pm 86.84^{\mathrm{bc}}$ \\
\hline
\end{tabular}

Means within a column followed by the same letter are not significantly different at $p<0.05$

The asterisk indicates that nutrient levels in females and males were significantly different for the same food source at $p<0.05$

composition in nectars, measured as sucrose/hexose (glucose + fructose) ratio, Petanidou (2005) found that hoverflies prefer high hexose-nectars. These types of nectars are produced in larger amounts, are more common, more diluted and easily absorbed in the gut of insects than sucrose-rich nectars (Nicolson 1998). Hexose-rich nectars are commonly found in open flowers that can be more easily explored by insects with a short proboscis, such as hoverflies (Petanidou 2005). In addition, nectars can be the only source of water in many agroecosystems (Petanidou 2007). Honey was used in this study as a mimic of a hexose-rich nectar. Although honey can include trace amounts of proteins, enzymes or amino acids, mainly due to the presence of pollen, it is composed of high levels of glucose and fructose (that can account for 85-99\% of honey dry matter) and low levels of sucrose (Ball 2007; Krell 1996). Longevity of individuals fed on honey was similar to that fed on glucose only which shows the importance of this monosaccharide for the lifespan of hoverflies. However, nutrient levels determined in individuals fed on honey were significantly lower than on glucose, probably because the concentration of this sugar in honey $(10 \%)$ was about 3.8 times below its concentration in the glucose solution $1 \mathrm{M}$ (considering that the concentration of glucose in honey is, on average, $35 \%$-w/ $\mathrm{w}$ - and density is about $1.36 \mathrm{~kg} \mathrm{l}^{-1}$ ) (Krell 1996).

Honeydew is another important source of energy for hoverflies. The black scale honeydew favored the survival of E. balteatus, mainly in the case of females, when compared with the water only treatment, but longevity was significantly lower than on the other food sources. Honeydew has a greater diversity of sugars and other nutrients when compared with nectars and can be the main carbohydrate source in many agroecosystems (Wäckers and Swaans 1993). The black scale honeydew is mainly composed of the sugars trehalose $\left(193.3 \mathrm{mg} \mathrm{g}^{-1}\right)$, sucrose $\left(25.0 \mathrm{mg} \mathrm{g}^{-1}\right)$, glucose and melibiose $\left(24.9 \mathrm{mg} \mathrm{g}^{-1}\right.$ ) (L. Torres, data not published). However, in comparison to nectar, honeydew has often an inferior nutritional suitability for natural enemies (Wäckers 2001), which can be based on the action of secondary metabolites produced by plants against herbivorous insects (Kos et al. 2011) or on pest synthesized compounds (Wäckers 2000). Both sugar composition and the occurrence of plant-derived defensive chemicals can explain the results obtained with $E$. balteatus fed on black scale honeydew. Nevertheless, honeydew can be an alternative or supplementary resource as it was already reported for E. balteatus (Langoya and van Rijn 2008; van Rijn et al. 2006) and for males of Syrphus ribesii (L.) (Diptera: Syrphidae) fed on nectar and honeydew from Acer (Gilbert 1984). Moreover, when hoverflies are unable to exploit the nectar, i.e., when the proboscis length is not adequate to the flower anatomy, honeydew may easily be explored. Besides, the black scale honeydew may represent a source of sugars helping to support hoverflies in agricultural areas where vegetation has been removed. 
Consumption of pollen resulted in high longevity, similar to that obtained by individuals fed on glucose and honey. Moreover, results obtained for nutrient levels showed that pollen was a source of fructose and other sugars, probably because beecollected pollen used in this study has small amounts of honey that bees use to aggregate pollen grains. In the field, pollen is the main source of proteins for hoverflies and, usually, females consume larger amounts of pollen grains than males (Irvin et al. 1999; Haslett 1989a; Hickman et al. 1995; Wratten et al. 1995). Pollen is considered an essential resource for $E$. balteatus females that are unable to produce eggs when fed on sucrose and honeydew, but promptly begin oviposition when pollen is provided (Lundgren 2009). Moreover, Haslett (1989a) showed that the amount of pollen consumed by hoverflies depends on the stage of reproduction. Males need an initial amount of pollen for spermatogenesis while females need greater amounts, and for a longer period, for ovary maturation and egg production (Branquart and Hemptinne 2000; Gilbert 1981, 1985). Hoverflies were able to convert sugars into lipids, contrarily to many species of parasitoids (Fadamiro et al. 2005; Giron and Casas 2003). Apparently, pollen, honey and honeydew did not contribute to replace capital lipids. But, for hoverflies fed on pollen and honey + pollen, differences found in lipid levels could be influenced by the activation of gametogenesis in those individuals (this should be clarified in further studies).

In conclusion, hoverflies mainly benefited from the consumption of sugars and pollen that significantly increased longevity and contributed to the maintenance of the nutrient levels. Honeydew was a less suitable food source when compared with the other types of food tested, although it improved the longevity of hoverflies when compared with water fed individuals. The occurrence of these resources in agroecosystems is crucial to satisfy the specific needs of hoverflies and maintain them in the crop.

Acknowledgments This study was financially supported by FEDER Funds throughout Programa Operacional Factores de Competitividade - COMPETE and National Funds throughout FCT - Fundação para a Ciência e Tecnologia, within the project PTDC/AGR-AAM/100979/2008 - Increasing functional biodiversity in olive groves to enhance conservation biological control of insect pests.

\section{References}

Ambrosino MD, Luna JM, Jepson PC, Wratten SD (2006) Relative frequencies of visits to selected insectary plants by predatory hoverflies (Diptera: Syrphidae), other beneficial insects, and herbivores. Environ Entomol 35:394-400

Ball DW (2007) The chemical composition of honey. J Chem Edu 84:1643-1647

Bianchi FJ, Booij CJ, Tscharntke T (2006) Sustainable pest regulation in agricultural landscapes: a review on landscape composition, biodiversity and natural pest control. Proc Biol Sci 273:1715-1727

Branquart E, Hemptinne J-L (2000) Development of ovaries, allometry of reproductive traits and fecundity of Episyrphus balteatus (Diptera: Syrphidae). Eur J Entomol 97: $165-170$

Bugg RL, Colfer RG, Chaney WE, Smith HA, Cannon J (2008) Flower flies (Syrphidae) and other biological control agents for aphids in vegetable crops. Division of Agriculture and Natural Resources, University of California. Publication 8285. California, USA, p. 25

Colley MR, Luna JM (2000) Relative attractiveness of potential beneficial insectary plants to aphidophagous hoverflies (Diptera: Syrphidae). Environ Entomol 29:1054-1059

Davidson EW, Segura BJ, Steele T, Hendrix DL (1994) Microorganisms influence the composition of honeydew produced by the silverleaf whitefly, Bemisia argentifolii. J Insect Physiol 40:1069-1076

Fadamiro HY, Chen L, Onagbola EO, Graham LF (2005) Lifespan and patterns of accumulation and mobilization of nutrients in sugar fed phorid fly Pseudacteon tricuspis. Physiol Entomol 30:212-224

Gilbert FS (1981) Foraging ecology of hoverflies: morphology of the mouthparts in relation to feeding on nectar and pollen in some common urban species. Ecol Entomol 6: 245-262

Gilbert FS (1984) Thermoregulation and the structure of swarms in Syrphus ribesii (Syrphidae). Oikos 42:249-255

Gilbert FS (1985) Diurnal activity patterns in hoverflies (Diptera: Syrphidae). Ecol Entomol 10:385-392

Giron D, Casas J (2003) Lipogenesis in an adult parasitic wasp. J Insect Physiol 49:141-147

Haenke S, Scheid B, Schaefer M, Tscharntke T, Thies C (2009) Increasing syrphid fly diversity and density in sown flower strips within simple vs. complex landscapes. J Appl Ecol 46:1106-1114

Haslett JR (1989a) Adult feeding by holometabolous insects: pollen and nectar as complementary nutrient sources for Rhingia campestris (Diptera: Syrphidae). Oecologia 81: 361-363

Haslett JR (1989b) Interpreting patterns of resource utilization: randomness and selectivity in pollen feeding by adult hoverflies. Oecologia 78:433-442

Hickman JM, Lövei GL, Wratten SD (1995) Pollen feeding by adults of the hoverfly Melanostoma fasciatum (Diptera: Syrphidae). New Zeal J Zool 22:387-392

Irvin NA, Wratten SD, Frampton CM, Bowie MH, Evans AM, Moar NT (1999) The phenology and pollen feeding of three hover fly (Diptera: Syrphidae) species in Canterbury, New Zealand. New Zeal J Zool 26:105-115 
Kos M, Kabouw P, Noordam R, Hendriks K, Vet LM, van Loon JJA, Dicke M (2011) Prey-mediated effects of glucosinolates on aphid predators. Ecol Entomol 36:377-388

Krell R (1996) Value-added products from beekeeping. Food and Agriculture Organization of the United Nations, Rome, p 413

Ksantini M (2003) Contribution à l'étude de la dynamique des populations du psylle de 1'olivier Euphyllura olivina (Costa) (Homoptera - Sternorhyncha - Aphalaridae) et de sa nuisibilité dans la région de $\mathrm{Sfax}$. $\mathrm{PhD}$ Thesis. Faculté des Sciences de Sfax, Sfax, Tunisia

Langoya LA, van Rijn PCJ (2008) The significance of floral resources for natural control of aphids. Proc Neth Entomol Soc Meet 19:67-74

Laubertie EA, Wratten SD, Hemptinne J-L (2012) The contribution of potential beneficial insectary plant species to adult hoverfly (Diptera: Syrphidae) fitness. Biol Control 61:1-6

Lundgren JG (2009) Relationships of natural enemies and nonprey foods. Series: progress in biological control, vol 7. Springer, Heidelberg, p 453

Nicholls CI, Parrilla M, Altieri MA (2001) The effects of a vegetational corridor on the abundance and dispersal of insect biodiversity within a northern California organic vineyard. Landscape Ecol 16:133-146

Nicolson SW (1998) The importance of osmosis in nectar secretion and its consumption by insects. Am Zool 38:418-425

Nicolson SW, Thornburg RW (2007) Nectar Chemistry. In: Nicolson SW, Nepi M, Pacini E (eds) Nectaries and nectar. Springer, Heidelberg, pp 215-264

Noguera V, Verdú MJ, Gómez Cadenas A, Jacas JA (2003) Ciclo biológico, dinámica poblacional y enemigos naturales de Saissetia oleae Olivier (Homoptera: Coccidae), en olivares del Alto Palancia (Castellón). Bol Sanid Veg Plagas 29:495-504

Panis A (1977) Lecaninos (Homoptera, Coccoidea, Coccidae) dentro del plan de lucha integrada en la citricultura mediterránea. Bol Sanid Veg Plagas 3:111-119

Petanidou T (2005) Sugars in Mediterranean floral nectars: an ecological and evolutionary approach. J Chem Ecol 31: $1065-1088$

Petanidou T (2007) Ecological and evolutionary aspects of floral nectars in Mediterranean habitats. In: Nicolson SW, Nepi M, Pacini E (eds) Nectaries and nectar. Springer, Heidelberg, Germany, pp 343-375

Petanidou T, van Laere AJ, Smets E (1996) Change in floral nectar components from fresh to senescent flower of Capparis spinosa (Capparidaceae), a nocturnally flowering Mediterranean shrub. Plant Syst Evol 199:79-92

Petanidou T, van Laere AJ, Ellis WN, Smets E (2006) What shapes amino acid and sugar composition in Mediterranean floral nectars? Oikos 115:155-169

Pineda A, Marcos-García A (2008) Use of selected flowering plants in greenhouses to enhance aphidophagous hoverfly populations (Diptera: Syrphidae). Ann Soc Entomol Fr 44:487-492

Pinheiro LA, Torres L, Raimundo J, Santos SAP (2013a) Effect of seven species of the family Asteraceae on longevity and nutrient levels of Episyrphus balteatus. BioControl 58: 797-806
Pinheiro LA, Torres L, Raimundo J, Santos SAP (2013b) Effect of floral resources on longevity and nutrient levels of Episyrphus balteatus (Diptera: Syrphidae). Biol Control 67:178-185

R Core Team (2014) R: a language and environment for statistical computing. R Foundation for Statistical Computing, Vienna. http://www.R-project.org

Ricarte A, Marcos-García MA, Moreno CE (2011) Assessing the effects of vegetation type on hoverfly (Diptera: Syrphidae) diversity in a Mediterranean landscape: implications for conservation. J Insect Conserv 15: 865-877

Rojo S, Gilbert FS, Marcos-Garcia MA, Nieto JM, Mier MP (2003) Revisión mundial de los sírfidos depredadores (Diptera, Syrphidae: Syrphinae) y sus presas, CIBIO edn. Alicante, Spain, 319 pp

Santos SAP, Pereira JA, Raimundo A, Torres LM, Nogueira AJA (2010) Seasonal synchrony between Saissetia oleae (Olivier) (Hemiptera: Coccidae) and coccinellid species in Portuguese olive groves in different management systems. Bull Insectol 63:51-57

Scholz D, Poehling HM (2000) Oviposition site selection of Episyrphus balteatus. Entomol Exp Appl 94:149-158

SPSS Inc., IBM Company (2010) IBM, SPSS Statistic for Windows, version 19.0.0. New York

Stanley RG, Linskins HF (1974) Pollen: biology, biochemistry management. Springer, New York, p 307

van Handel E (1985a) Rapid determination of glycogen and sugars in mosquitoes. $\mathrm{J}$ Am Mosquito Control 1: 299-301

van Handel E (1985b) Rapid determination of total lipids in mosquitoes. J Am Mosquito Control 1:302-304

van Rijn PCJ, Kooijman J, Wäckers FL (2006) The impact of floral resources on syrphid performance and cabbage aphid biological control. IOBC/WPRS Bull 29:149-152

van Rijn PCJ, Kooijman J, Wäckers FL (2013) The contribution of floral resources and honeydew to the performance of predatory hoverflies (Diptera: Syrphidae). Biol Control 67:32-38

Wacht S, Lunau K, Hansen K (2000) Chemosensory control of pollen ingestion in the hoverfly Eristalis tenax by labellar taste hairs. J Comp Physiol A 186:193-203

Wäckers FL (1999) Gustatory response by the hymenopteran parasitoid Cotesia glomerata to a range of nectar and honeydew sugars. J Chem Ecol 25:2863-2877

Wäckers FL (2000) Do oligosaccharides reduce the suitability of honeydew for predators and parasitoids? A further facet to the function of insect-synthesized honeydew sugars. Oikos 90:197-201

Wäckers FL (2001) A comparison of nectar- and honeydew sugars with respect to their utilization by the hymenopteran parasitoid Cotesia glomerata. J Insect Physiol 47: 1077-1084

Wäckers FL, Swaans CPM (1993) Finding floral nectar and honeydew in Cotesia rubecula: random or directed? Proc Exp Appl Entomol 4:67-72

White MH, Wratten SD, Berry NA, Weigmann U (1995) Habitat manipulation to enhance biological control of brassicae pests by hoverflies (Diptera: Syrphidae). J Econ Entomol 88:1171-1176 
Wratten SD, White AJ, Bowie MH, Berry NA, Weigmanni U (1995) Phenology and ecology of hoverflies (Diptera: Syrphidae) in New Zealand. Environ Entomol 24:595-600

L. A. Pinheiro is a research fellow at ESA/IPB. She is currently doing her $\mathrm{PhD}$ in biosystems engineering focused on pest-natural enemies interactions in sustainable olive groves.

L. M. Torres if a Full Professor at UTAD. Her main focus is on conservation biological control, enhancement of natural enemies in agroecosystems and their role in sustainable production systems.

J. Raimundo is a $\mathrm{PhD}$ student at IMAR/CMA/UC. He was responsible for nutrient analysis.

S. A. P. Santos is an assistant researcher at CIMO/ESA/IPB. Her research interests include the study of biodiversity of natural enemies in agroecosystems and population ecology of arthropod predators, focusing on Coccinellidae and Syrphidae. 